UDC 621.762.4

\title{
WEAR RESISTANT HARD ALLOYS FOR AGRICULTURAL MACHINES ELEMENTS
}

\author{
Ihor Koval; Lyudmyla Bodrova; Halyna Kramar; Sergiy Marynenko; \\ Yaroslav Kovalchuk; Nazariy Kondzelko
}

\author{
Ternopil Ivan Puluj National Technical University, Ternopil, Ukraine
}

\begin{abstract}
Summary. Hard alloys based on titanium carbide, alloying by vanadium carbide and tungsten carbide (nano tungsten carbide) with nickel chromium binder have been developed in order to replace tungsten cobalt hard alloys used for the manufacturing of wear-resistant parts and cutting elements of plows, cultivators and other agricultural machines. These alloys possess higher hardness and wear resistance and provide reliable and longlasting operation during exploitation. Research of tribotechnical properties of $\mathrm{TiC}-\mathrm{VC}-\mathrm{WC} / \mathrm{nano}-\mathrm{WC}-\mathrm{NiCr}$ hard alloys at different sliding speeds on chrome steel AISI 52100 and AISI 5040 has been carried out on a M$22 M$ friction machine according to scheme the shaft (counter-shaft) - partial insert (alloy). Friction coefficient and weight wear have been determined in given research depending on the sliding speed and chemical composition of the alloys (content of WC/nanoWC 5, 10, 15\% (wt.)) under test conditions: sliding speed 1, 2, $3 \mathrm{~m} / \mathrm{s}$, constant load 1,5 MPa, the friction path at each of sliding speeds is $5 \mathrm{~km}$. The character and wear-mechanism of the alloys have been determined by metallographic investigations of the friction surface using the REM-106 microscope. It has been found that alloying by nano-WC reduces the friction coefficient and weight wear compared to alloys with fine WC. The main mechanism of the researched alloys wear is abrasion. The analysis of the wear zone has testified that it consists of two sections-abrasive wear and tribo layer, which contains a considerable amount of oxygen and the alloy's and processed material's elements. The obtained level of tribotechnical characteristics of the alloys makes it possible to recommend them for the elements of agricultural machines operating under the friction and wear.
\end{abstract}

Key words: microstructure, hard alloys, wear resistant.

Statement of the problem. Tungsten cobalt hard alloys are widely used in various industry branches, including agriculture, for the manufacture of wear-resistant parts, as well as devices with cutting surfaces [1-3]. Examples of these alloys' use in agricultural machinery are: the soldered and replaceable plate coulters of seeders, cutting parts of plows, cultivators, etc. However, tungsten carbide is quite expensive and under certain operating conditions the hardness and wear resistance of WC-Co alloys are insufficient, so it is a relevant task to design carbide/titanium carbide/carbonitride hard alloys with higher hardness and 3 times lower density, compared to tungsten carbide, for WC-Co alloys' replacement.

Analysis of the available investigations. The improvement of physical, mechanical and operating properties of titanium carbide-based hard alloys capable for effective replacement of tungsten carbide alloys is achieved by alloying the carbide base with other carbides, including nano-sized ones, in particular tungsten carbide, as well as choosing the metal binder which reduces the wetting angle [4-6]. Polycarbide-based hard alloys (TiC-VC, TiC-VC-WC, TiC-VC-nanoWC) with nickel-chromium binder have a hardness of $90 \ldots 93 \mathrm{HRA}$, Vickers hardness of $14.5 \ldots 16.3 \mathrm{GPa}$, transverse rupture strength of $0.9 \ldots 1.2 \mathrm{GPa}$, crack resistance $7.5 \ldots 8.8 \mathrm{MPa} \cdot \mathrm{m}^{1 / 2}[7]$.

The use of nano-sized alloying carbides reduces the porosity, promotes microstructure grinding and enhances alloys' mechanical properties. It is known that structurally sensitive mechanical properties (hardness, strength) can be regulated by structure dispersing. Therefore, 
the alloying of titanium carbide alloys with tungsten carbide and tungsten nano carbide allows to get the optimal ratio of alloys' strength and hardness [8-12].

The wear resistance and heterogeneity of hard alloys' structure are important factors to provide reliable and durable work of agricultural machinery cutting parts to be used under conditions of intensive friction [13-16]. Titanium carbide-based alloys have a core/rim microstructure which ensures their high wear resistance [17].

The Objective of the work is wear resistance of TiC-VC-NiCr hard alloys with the nano- and fine WC additives.

Statement of the task. To research the effect of nano- and fine WC additives on tribotechnical properties and the wear mechanism of $\mathrm{TiC}-\mathrm{VC}-\mathrm{NiCr}$ hard alloys at different sliding speeds on AISI 52100 and AISI 5040 steels.

Materials, methods and results of investigation. Cylindrical specimens of $6 \mathrm{~mm}$ diameter and $12 \mathrm{~mm}$ height were made by powder metallurgy method. Non-stoichiometric powders of titanium, vanadium carbides, tungsten carbides (fine $(\mathrm{d}=1-2 \mu \mathrm{m}$ ) or nano $(\mathrm{d}=100-200 \mathrm{~nm})$ produced by «Nanostructured and Amorphus Materials, Inc.» (Houston, USA)), nickel and chromium with a metal content of $99.8 \%$ (wt.) were used for alloys' manufacture. In all alloys, the binder content was constant $-18 \%$ (wt.) at $\mathrm{Ni}: \mathrm{Cr}=3: 1$ ratio. The sintering temperature was $1350^{\circ} \mathrm{C}$, the isothermal holding time -20 minutes.

The chemical composition of the researched alloys is presented in Table 1.

Table 1

Chemical composition of alloys

\begin{tabular}{|c|c|c|c|c|}
\hline \multirow{2}{*}{ Alloy numbers } & $\mathrm{TiC}$ & $\mathrm{VC}$ & WC & $\mathrm{NiCr}$ \\
\hline & \multicolumn{4}{|c|}{$\%$ (weight) } \\
\hline 1 & 72 & \multirow{6}{*}{5} & 5 & \multirow{6}{*}{18} \\
\hline 2 & 67 & & 10 & \\
\hline 3 & 62 & & 15 & \\
\hline 4 & 72 & & 5 (nano) & \\
\hline 5 & 67 & & 10 (nano) & \\
\hline 6 & 62 & & 15 (nano) & \\
\hline
\end{tabular}

Research of alloys' tribotechnical properties was carried out under conditions of dry friction on the machine friction $\mathrm{M}-22 \mathrm{M}$ according to the scheme of shaft (counter-shaft) partial insert (alloy) at different sliding speeds on steels AISI 52100 and AISI 5040. Test conditions were as following: sliding speed $-1,2,3 \mathrm{~m} / \mathrm{s}$, constant load $-1.5 \mathrm{MPa}$, friction length at each speed $-5 \mathrm{~km}$. The friction coefficient was determined by the friction force measurement data. The displacement sensor B8-884 (0.01 mm sensitivity) determined linear wear of the friction pair. The weight wear of the friction pair materials was measured at analytical weights of ADV-200 (accuracy $0.0005 \mathrm{~g}$ ). To plot the corresponding dependencies all parameters were determined on three samples. The temperature was measured by a chromelcopkel thermocouple, placed at a distance of $1 \mathrm{~mm}$ from the sample surface.

The wear mechanism of the alloys was determined by metallographic researches of the friction surface on a SELMI REM-106 microscope.

Figure 1 presents the investigation results the friction coefficient, linear and weight wear of samples and counter-shaft while sliding on steel AISI 52100 depending on the sliding speed and chemical composition of alloys at a constant load of 1.5 MPa. 


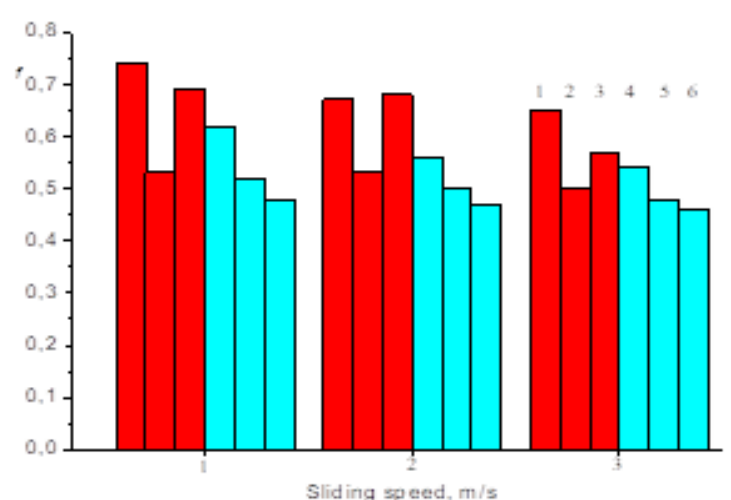

a)

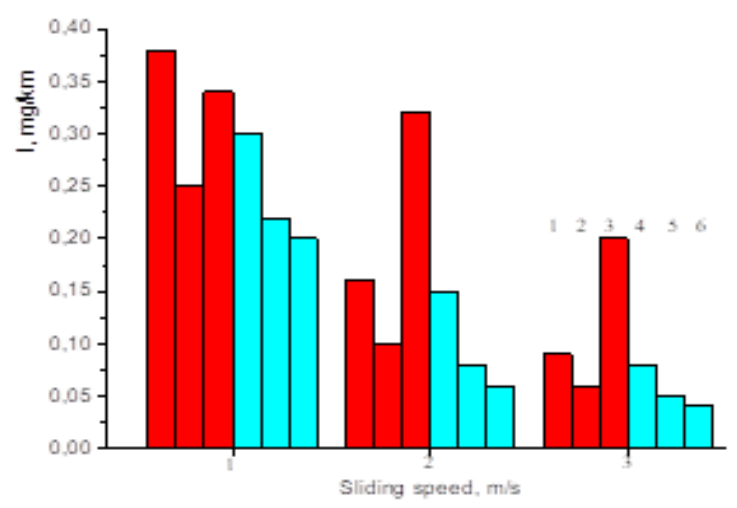

c)

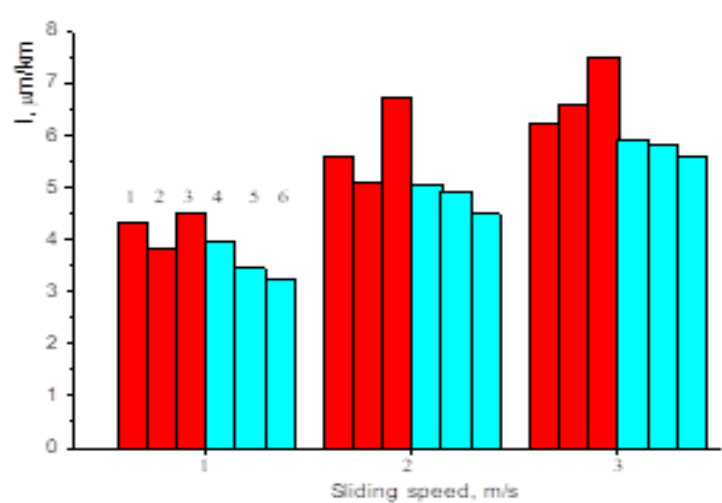

b)

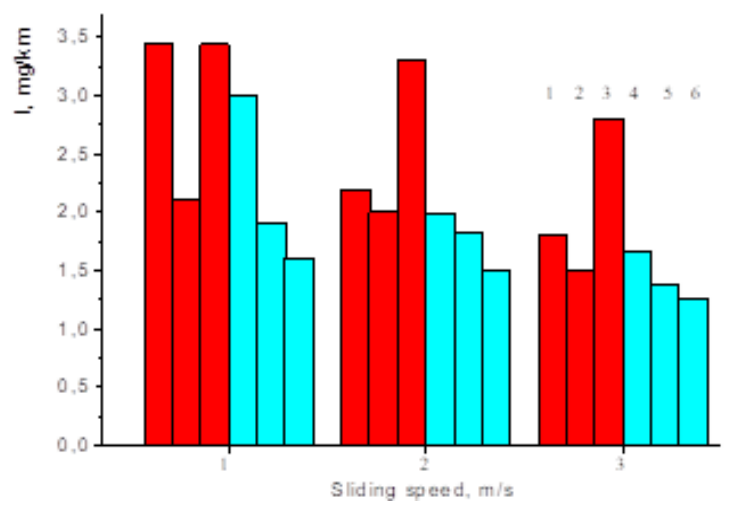

d)

Figure 1. Dependences of the friction coefficient (a), linear wear (b) and weight wear of the samples (c) and the control body $(\mathrm{d})$ on the sliding speed (sample-steel AISI 52100, $\mathrm{P}=1.5 \mathrm{MPa})(1-6-$ alloy numbers)

The research results showed that increase of nano tungsten carbide content from 5 to $15 \%$ (wt.) decreases the friction coefficient from 0.68 to 0.46 . For alloys alloyed with fine WC, an alloy 2 with $10 \%$ (wt.) WC has the smallest friction coefficient at sliping speed $3 \mathrm{~m} / \mathrm{s}-0.5$. At all sliding speeds, alloys containing 15\% (wt.) nano WC and 10\% (wt.) fine WC have the minimum friction coefficient, linear and weight wear of the specimens. For all nano-WC alloys, as the sliding speed increases, the coefficient of friction and weight wear decreases, whereas for alloys with fine-grained WC, such dependence has minimum for alloy 2 with $10 \%$ (wt.) WC.

Increasing the sliding speed causes the friction pair temperature to rise. It was found that the maximum temperature in the friction zone is $174^{\circ} \mathrm{C}$, thus activating diffusion and oxidation processes that change the temperature-force conditions of wear.

Alloy 6 with $15 \%$ (wt.) nano WC has the highest tribotechnical properties - friction coefficient 0.48 , linear wear of friction pair $3.25 \mu \mathrm{m} / \mathrm{km}$ at sliding speed $1 \mathrm{~m} / \mathrm{s}$, weight wear of alloy and control body $0.04 \mathrm{mg} / \mathrm{km}$ and $1.26 \mathrm{mg} / \mathrm{km}$, respectively at sliding speed $3 \mathrm{~m} / \mathrm{s}$.

Thus, the dispersion of alloying tungsten carbide significantly affects on the tribotechnical properties of the alloys - alloys alloyed with fine WC have 2-31\% higher friction coefficient and 8-33\% higher linear wear compared nano WC.

One of the reasons for different behaviour of alloys during wear is the fact that hardness of alloys with fine tungsten carbide decreases with the increase of WC content to $15 \%$ (wt.), because WC has lower hardness than TiC. In case of alloying nano WC, this dependence is directly proportional - with the increase of WC content, the Vickers hardness increases from 
14.3 GPa to $15.8 \mathrm{GPa}$ due to the formation of fine-grained structure and dispersion strengthening of binder by tungsten [8].

Figure 2 presents the results of the influence of nano tungsten carbide content on tribotechnical properties of alloys at sliding on AISI 5040 steel.

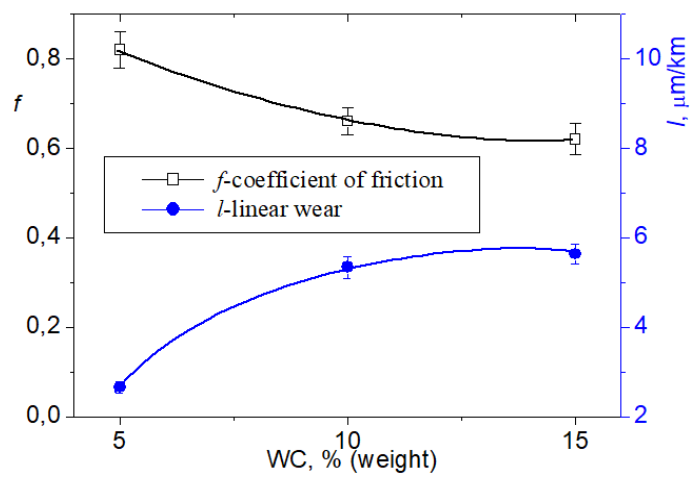

a)

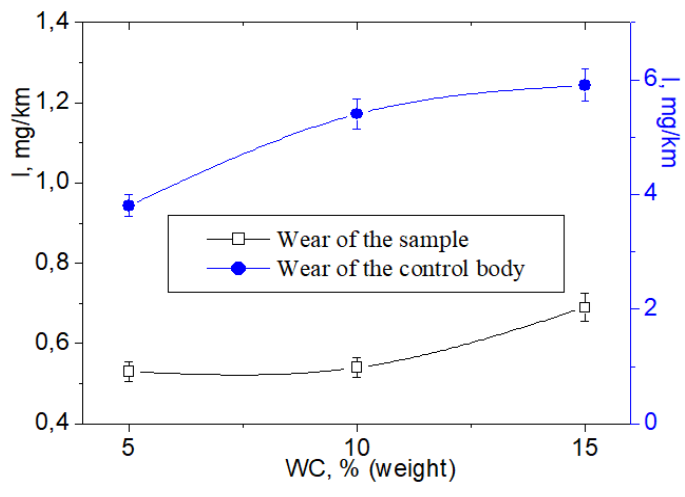

b)

Figure 2. Dependences of the friction coefficient, linear wear (a) and weight wear of the samples and the control body (b) on the content of nano WC (sample-steel AISI 5040, V=1 m/s; P = 1.5 MPa)

A similar trend was found for alloys alloyed with nano WC when sliding on AISI 5040 steel, but the tribotechnical properties of this friction pair were lower compared to the pair of alloys-AISI 52100 steel. In the pair of alloy 6-steel AISI 52100 the friction coefficient was 0.48 , while in the pair of alloy 6-AISI 5040 steel it was equal to 0.62 . As the content of nano WC increases to $15 \%$ (wt.) (Figure 2), the linear wear of the friction pair increases from 2.66 to 5.64 $\mu \mathrm{m} / \mathrm{km}$, and the weight wear of the control body increases from 3.8 to $5.9 \mathrm{mg} / \mathrm{km}$, while the alloy weight wear remains at $0.53-0.69 \mathrm{mg} / \mathrm{km}$.

In the researched alloys with nano WC carbide grains with core-rim structure have a size of $0.75 \ldots 0.8 \mu \mathrm{m}$, homogeneous carbide grains $-0.55 \ldots 0.6 \mu \mathrm{m}$ and the thickness of the binder does not exceed 0.4-0.5 $\mu \mathrm{m}$ [18]. Since the carbide grains size is bigger than the binder thickness, carbides make the predominant contribution to the destruction, dispersion strengthened binder prevents the microcrack growth (Figure 3 a).

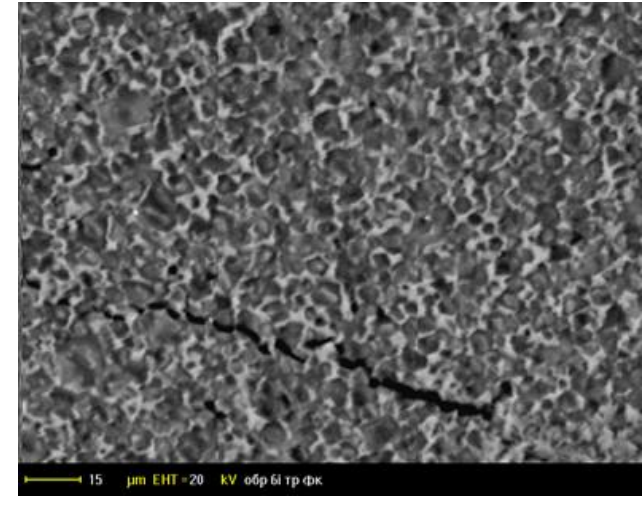

a)

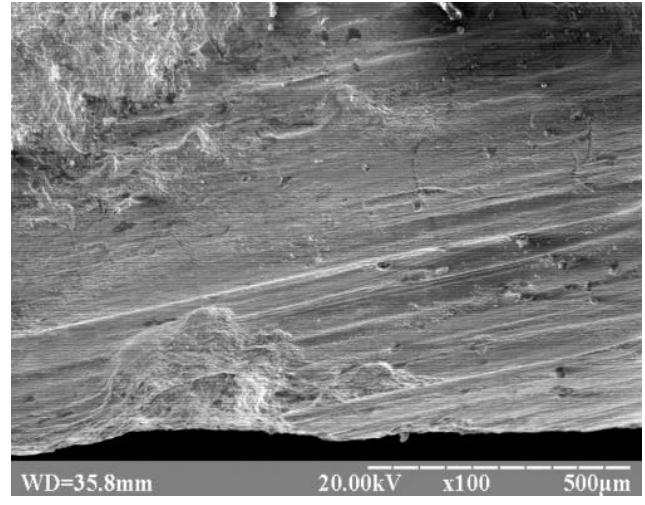

b)

Figure 3. Microcrack (a) and local wear alloy 6 with 15\% (wt.) nano WC 
It was found that the main mechanism of alloys' local wear has been abrasive abrasion, which main features are: cracking of carbide grains and removal their parts with the formation traces of friction, the destruction of the intergrain boundaries, and crumble of small carbides. As a result, there were friction flows and small craters formed on the surface (Figure $3 \mathrm{~b}$ ).

In the process of friction, the factors of wear are: adsorption, oxidation and mutual diffusion in the friction pair. The analysis of the wear zone and the elements distribution shows that in addition to the abrasive abrasion area, there is a tribolayer, which contains a considerable amount of oxygen and elements of the alloys and the counter-shaft steel (Table 2) and consists mainly of oxides of iron, titanium and tungsten.

Table 2

Chemical composition of the alloys' surface layer at sliding on steel AISI 5040 depending on the WC content and dispersion

\begin{tabular}{|c|c|c|c|c|c|c|c|c|}
\hline \multirow{2}{*}{ WC, \% (weight) } & $\mathrm{O}$ & $\mathrm{W}$ & $\mathrm{Ti}$ & $\mathrm{Fe}$ & $\mathrm{Ni}$ & $\mathrm{V}$ & Other elements \\
\cline { 2 - 8 } & \multicolumn{8}{|c|}{ at \% } \\
\hline 5 & 48,27 & 7,42 & 16,06 & 17,7 & 4,46 & 2,83 & 3,27 \\
\hline 5 nano & 48,49 & 8,31 & 16,62 & 18,34 & 3,62 & 2,41 & 2,21 \\
\hline 10 nano & 44,82 & 10,66 & 18,49 & 19,62 & 1,97 & 1,75 & 2,69 \\
\hline 15 nano & 49,38 & 15,31 & 24,83 & 7,52 & 0,75 & 1,13 & 1,08 \\
\hline
\end{tabular}

Thus, in addition to abrasive abrasion, the alloys' wear also occurs through oxidation and diffusion mechanisms.

Conclusions. It was found that TiC-VC-WC/nanoWC-NiCr alloys have high tribotechnical properties - friction coefficient pair with AISI 52100 steel - 0,46, with AISI $5040 \mathrm{steel}-0,62$, linear wear - up to $5,9 \mu \mathrm{m} / \mathrm{km}$, weight wear - up to $0,3 \mathrm{mg} / \mathrm{km}$, which makes it possible to recommend them for the replacement of tungsten carbide alloys used for parts of agricultural machinery operating under heavy and intensive wear conditions.

Alloying of alloys by nano tungsten carbide, compared with fine tungsten carbide, reduces the friction by $2-31 \%$, linear wear by $8-33 \%$.

Increase of the sliding speed from $1 \mathrm{~m} / \mathrm{s}$ to $3 \mathrm{~m} / \mathrm{s}$ leads to the reduction of the friction coefficient and weight wear, as well as to the increase the friction pair temperature. The regularities of tribotechnical properties changes of the researched alloys were kept at all sliding speeds.

The main mechanisms of alloys' wear were defined as following: abrasive abrasion, oxidation and diffusion. In the process of abrasive abrasion there was noticed carbide grains' cracking and crumble of small carbides. As the temperature increases in the contact zone, a tribolayer containing a considerable amount of oxygen and elements of alloys and counterparts, in particular, oxides of iron, titanium and tungsten, is being formed on the alloys' surface.

\section{References}

1. Prokopiv M. M., Kharchenko O. V., Tsap I. V. Metalorizal'nomu instrumentu z tverdoho splavu T5K10 novu yakist' (T5K10 hard-alloy metal-cutting tool- new quality). Porodorazrushayushchyy y metalloobrabatyvayushchyy ynstrument - tekhnyka y tekhnolohyya eho yz hotovlenyya y prymenenyya. 2012. Vol. 20. P. 422-425. [In Ukrainian].

2. Brookes Kenneth J. A. Hardmetalls still at the cutting edge. Metal Powder Report. 1999. Vol. 54. No. 9. P. 21-23. https://doi.org/10.1016/S0026-0657(99)81167-9

3. Bellosi A., Calzavarini R., Faga M. G. et al. Characterisation and application of titanium carbonitride-based cutting tools. J. of Mat. Proc. Techn. 2003. 143-144. Pp. 527-532. https://doi.org/10.1016/S09240136(03)00339-X

4. Yan Li, Ning Liu, Xiaobo Zhang, Chunlan Rong Effect of WC content on the microstructure and mechanical properties of $(\mathrm{Ti}, \mathrm{W})(\mathrm{C}, \mathrm{N})-\mathrm{Co}$ cermets. Int. Journal of Refractory Metals \& Hard Materials. Accepted Manuscript. 2008. Vol. 26. Issue 1. P. 33-40. https://doi.org/10.1016/j.ijrmhm.2007.01.003 
5. Kubarsepp J., Reshetnyak H., Pirso J. Features of Wear of TiC-base Hardmetals. Proceeding of 1998 Powder Metallurgy World Congress and Exhibition. Granada (Spain), 1998. Vol. 4. P. 75-79.

6. Li L., Liu N., Zhang X., Rong C. Effect of WC content on the microstructure and mechanical properties of $(\mathrm{Ti}, \mathrm{W})(\mathrm{C}, \mathrm{N})-\mathrm{Co}$ cermets. Int. Journal of Refractory Metals \& Hard Materials. Accepted Manuscript. 2006. $25 \mathrm{p}$.

7. Koval I., Bodrova L., Kramar H. et al. Relationship between the structure and properties of polycarbide based hard alloys with nano-WC addings. Proceedings of the World Congress and Exhibition PM-2014 EPMA. London, UK., 2014. 19 P3 EP140178. 5 p.

8. Gevorkyan E. S., Gytsalenko Ju. G., Prokopiv N. M. Effect of Nanosized Particles of Tungsten Monocarbide on the Properties of Hard-Alloy Cutting Materials. Scientific proceedings of Ukrainian Research Institute of Refractories named after A. S. Berezhnoy. 2010. No. 110. P. 313-318.

9. Jung J., Kang S. Effect of ultra-fine powders on the microstructure of Ti(C, N)- xWC -Ni cermets. URL: www.actamat-journals.com. Acta Materiala. 2004. No. 52. P. 1379. https://doi.org/10.1016/j.actamat. 2003.11.021

10. Rempel' A. A. Nanotekhnologii, svoystva i primeneniye nanostrukturirovannykh materialov (Nanotechnology, properties and applications of nanostructured materials). Uspekhi khimii, Tom. 76, no. 5, 2007, pp. 474-500. [In Russian]. https://doi.org/10.1070/RC2007v076n05ABEH003674

11. Chao S, Liu N, Yuan Y. P, Han C. L, Xu Y. D, Shi M, Feng J. P. Microstructure and mechanical properties of ultrafine $\mathrm{Ti}(\mathrm{C}, \mathrm{N})$-based cermets fabricated from nano/submicro starting powders. Ceram Int 2005, 31, pp. 851-886. https://doi.org/10.1016/j.ceramint.2004.09.013

12. Richter V., Poetschke J., Holke R., Michaelis A. Nanoscaled Hardmetals. Fiction or Reality? 18 Plansee Seminar, 2013. Reutte, Austria, 2013, 17 p. Bibliogr: 42 titles.

13. Khyzhnyak O. V., Kurdybaylo R. A., Khyzhnyak V. H. Znosostiyki bahatokomponentni karbidni Ti, V, Cr pokryttya na stali U10A ta tverdomu splavi T15K6 (Wear-resistant carbide multicomponent $\mathrm{Ti}, \mathrm{V}, \mathrm{Cr}$ coatings on U10A steel hard alloy T15K6). Naukovo-tekhnichnyy zhurnal "Problemy tertya ta znoshuvannya", no. 2(67), 2015, pp. 35-41. [In Ukrainian]. https://doi.org/10.18372/03702197.2(67).9452

14. Zaloga V. A., Kriviruchko D. V., Ya.Levedev V. et al. The effect of the nitrogen ion-beam implantation on adhesiveness of the WC-8Co hard alloy). Journal of Superhard Materials 34, pp. 44-48, 2012. https://doi.org/10.3103/S1063457612010054

15. Hignjak V. G, Calashnicov G. Y., Harchenko N. A. et al. The Structure, Composition and Properties Nitrided Alloys after Diffusion Metallization. Journal of Nano- and Electronic Physics. Vol. 7, No. 4, 6 pp. 2015.

16. Kolesnichenko V. G., Herrmann M., Varchenko V. T., Zgalat-Lozinskii O. B. Friction and wear of TiNSi3N4 nanocomposites against ShKh15 steel. Powder Metallurgy and Metal Ceramics. 2015. Vol. 53, no. 11-12. P. 680-687. https://doi.org/10.1007/s11106-015-9663-1

17. Bodrova L., Kramar H., Kovalchuk Y., Marynenko S., Koval I.. Structure Formation of Polycarbide-Based TiC-VC(NbC)-WC/nano WC Hard Alloys/Boundary field problems and computer simulation. Scientific Journal of Riga Technical University. 2018. Vol. 57. P. 35-40. https://doi.org/10.7250/bfpcs.2018.005

\section{Список використаної літератури}

1. Прокопів М. М., Харченко О. В., Цап І. В. Металорізальному інструменту з твердого сплаву Т5К10 - нову якість. Породоразрушающий и металлообрабатывающий инструмент - техника и технология его изготовления и применения. 2012. Выпуск 20. С. 422-425.

2. Brookes Kenneth J. A. Hardmetalls still at the cutting edge. Metal Powder Report. 1999. Vol. 54. No. 9. P. 21-23. https://doi.org/10.1016/S0026-0657(99)81167-9

3. Bellosi A., Calzavarini R., Faga M. G. et al. Characterisation and application of titanium carbonitride-based cutting tools. J. of Mat. Proc. Techn. 2003. Vol. 143. No. 144. P. 527-532. https://doi.org/10.1016/S09240136(03)00339-X

4. Yan Li, Ning Liu, Xiaobo Zhang, Chunlan Rong. Effect of WC content on the microstructure and mechanical properties of $(\mathrm{Ti}, \mathrm{W})(\mathrm{C}, \mathrm{N})-\mathrm{Co}$ cermets. Int. Journal of Refractory Metals \& Hard Materials. Accepted Manuscript. 2008. Vol. 26. Issue 1. P. 33-40. https://doi.org/10.1016/j.ijrmhm.2007.01.003

5. Kubarsepp J. Reshetnyak H., Pirso J. Features of Wear of TiC-base Hardmetals. Proceeding of 1998 Powder Metallurgy World Congress and Exhibition. Granada (Spain). 1998. Vol. 4. P. 75-79.

6. Li L., Liu N., Zhang X., Rong C. Effect of WC content on the microstructure and mechanical properties of $(\mathrm{Ti}, \mathrm{W})(\mathrm{C}, \mathrm{N})-\mathrm{Co}$ cermets. Int. Journal of Refractory Metals \& Hard Materials. Accepted Manuscript. 2006. $25 \mathrm{p}$.

7. Koval I., Bodrova L., Kramar H. Relationship between the structure and properties of polycarbide based hard alloys with nano-WC addings. Proceedings of the World Congress and Exhibition PM-2014 EPMA. London, UK, 2014. 5 p.

8. Gevorkyan E. S. Gytsalenko Ju. G., Prokopiv N. M. Effect of Nanosized Particles of Tungsten Monocarbide on the Properties of Hard-Alloy Cutting Materials. Scientific proceedings of Ukrainian Research Institute of Refractories named after A. S. Berezhnoy. 2010. No. 110. P. 313-318. 
9. Jung J., Kang S. Effect of ultra-fine powders on the microstructure of Ti $(\mathrm{C}, \mathrm{N})-\mathrm{xWC}-\mathrm{Ni}$ cermets. Acta Materiala. 2004. № 52. P. 1379. https://doi.org/10.1016/j.actamat.2003.11.021

10. Ремпель А. А. Нанотехнологии, свойства и применение наноструктурированных материалов. Успехи химии. Том 76. № 5. 2007. C.474-500. https://doi.org/10.1070/RC2007v076n05ABEH003674

11. Chao S, Liu N, Yuan Y. P, Han C. L, Xu Y. D, Shi M, Feng J. P. Microstructure and mechanical properties of ultrafine Ti $(\mathrm{C}, \mathrm{N})$-based cermets fabricated from nano/submicro starting powders. Ceram Int 2005. № 31. P. 85-186. https://doi.org/10.1016/j.ceramint.2004.09.013

12. Richter V. Poetschke J., Holke R., Michaelis A. Nanoscaled Hardmetals - Fiction or Reality? 18 Plansee Seminar, 2013. Reutte, Austria. 2013. 17 p.

13. Хижняк О. В., Курдибайло Р. А., Хижняк В. Г. Зносостійкі багатокомпонентні карбідні Ti, V, Cr покриття на сталі У10А та твердому сплаві Т15К6 (Wear-resistant carbide multicomponent $\mathrm{Ti}, \mathrm{V}, \mathrm{Cr}$ coatings on U10A steel hard alloy T15K6). Науково-технічний журнал «Проблеми тертя та зношування». № 2 (67). 2015. P. 35-41. https://doi.org/10.18372/0370-2197.2(67).9452

14. Zaloga V. A., Kriviruchko D. V, Levedev V. Ya. The effect of the nitrogen ion-beam implantation on adhesiveness of the WC-8Co hard alloy. Journal of Superhard Materials. No. 34. 2012. P. 44-48. https://doi.org/10.3103/S1063457612010054

15. Hignjak V. G. The Structure, Composition and Properties Nitrided Alloys after Diffusion Metallization. Journal of Nano- and Electronic Physics 2015. Vol. 7. No. 4. 6 p.

16. Kolesnichenko V. G., Ragulya A. V., Herrmann M., Varchenko V. T., Zgalat O. B. Friction and wear of TiN-Si3N4 nanocomposites against ShKh15 steel. Powder Metallurgy and Metal Ceramics. 2015. Vol. 53. No. 11-12. P. 680-687. https://doi.org/10.1007/s11106-015-9663-1

17. Bodrova L., Kramar H., Kovalchuk Y., Marynenko S., Koval I.. Structure Formation of Polycarbide-Based TiC-VC(NbC)-WC/nano WC Hard Alloys/Boundary field problems and computer simulation. Scientific Journal of Riga Technical University. 2018. Vol. 57. P. 35-40. https://doi.org/10.7250/bfpcs.2018.005

\title{
УДК 621.762.4
}

\section{ЗНОСОСТІЙКІ ТВЕРДІ СПЛАВИ ДЛЯ ДЕТАЛЕЙ СІЛЬСЬКОГОСПОДАРСЬКИХ МАШИН}

\section{Ігор Коваль; Людмила Бодрова; Галина Крамар; Сергій Мариненко; Ярослав Ковальчук; Назарій Кондзелко}

\author{
Тернопільський національний технічний університет \\ імені Івана Пулюя, Тернопіль, Украӥна
}

Резюме. Для заміни вольфрамокобальтових твердих сплавів, які використовують для виготовлення зносостійких деталей та різальних елементів плугів, культиваторів, лемехів та іншої сільськогосподарської техніки розроблено тверді сплави на основі карбіду титану, леговані карбідом ванадію і нанокарбідом вольфраму з нікель-хромовою зв'язкою. Ці сплави мають вищі твердість та зносостійкість і забезпечують надійну та довготривалу роботу в умовах експлуатації. Дослідження триботехнічних властивостей твердих сплавів $\mathrm{TiC}-\mathrm{VC}-\mathrm{WC} /$ нано-WC-NiCr при різних швидкостях ковзання по сталях ШХ15 i $40 X$ проводено на машині тертя М-22M за схемою вал (контртіло) частковий вкладиш (сплав). Визначено коефіцієнт тертя та вагове зношення залежно від швидкості ковзання і хімічного складу сплавів (вміст нано-WC/WC 5, 10, 15\% (мас.)) за умов випробувань: швидкість ковзання 1, 2, 3 м/с, постійне навантаження 1,5 МПа, шлях тертя на кожній зі швидкостей 5 км. $3 a$ допомогою металографічних досліджень поверхні тертя на мікроскопі РЕМ-106 визначено характер та механізм зношування сплавів. Встановлено, шо легування сплавів нано-WC сприяє зменшенню значень коефіцієнта тертя та вагового зношення порівняно зі сплавами з дрібнодисперсним ШС. Основним механізмом зношування досліджуваних сплавів є абразивне стирання. Аналіз зони зношування показав, щуо вона складається з двох ділянок-абразивного зношування й трибошару, який містить значну кількість кисню та елементів сплаву й оброблюваного матеріалу. Основними ознаками руйнування на ділянці абразивного зношування є розтріскування крупних карбідних зерен і викришування дрібних карбідних зерен. На трибоділяниі в адгезійному шарі (трибомасі) зосереджені оксиди заліза, нікелю, титану та вольфраму. Отриманий рівень триботехнічних характеристик сплавів дозволяє рекомендувати їх для деталей с/2 машин, щзо працюють в умовах тертя $і$ зношування.

Ключові слова: мікроструктура, тверді сплави, абразивне зношування. 